Article

\title{
Port-City Transition: Past and Emerging Socio-Spatial Imaginaries and Uses in Rotterdam's Makers District
}

\author{
Maurice Jansen ${ }^{1, *}$, Amanda Brandellero ${ }^{2}$ and Rosanne van Houwelingen ${ }^{1}$ \\ ${ }^{1}$ Erasmus Centre for Urban, Port and Transport Economics, Erasmus University Rotterdam, The Netherlands; E-Mails: \\ m.jansen@ese.eur.nl (M.J.), vanhouwelingen@ese.eur.nl (R.v.H.) \\ ${ }^{2}$ Department of Arts and Culture Studies, Erasmus School of History, Culture and Communication, Erasmus University \\ Rotterdam, The Netherlands; E-Mail: brandellero@eshcc.eur.nl \\ * Corresponding author
}

Submitted: 5 March 2021 | Accepted: 26 May 2021 | Published: 27 July 2021

\begin{abstract}
This article explores old and emerging socio-spatial imaginaries and uses of Rotterdam's Makers District. The district comprises two urban harbors-Merwe Vierhavens and Rotterdamsche Droogdok Maatschappij-historically in use as bustling trade, storage, and ship yarding nodes of the city's port activities. At the turn of the millennium, technological advancements made it possible to move many port-related activities out of the area and farther out of the city, gradually hollowing out these harbors' port-related economic foundations and opening opportunities for new uses and imaginaries. This article traces the transition by detailing how the boundary between the city and the port has become more porous in this district. It does so by offering original empirical evidence on the flows of users in and out of the area in recent years, based on location quotients, while also applying a content analysis of the profiles of companies and institutions currently inhabiting and working in these transformed port-city spaces. On the one hand, the results show how the ongoing port-city transition in Rotterdam's Makers District combines carefully curated interventions and infrastructure plans seeking to progressively adapt the area to new purposes, while maintaining some of its former functions. On the other hand, they highlight the pioneering role of more bottom-up initiatives and innovative urban concepts, springing from the creative industries and maker movement. The article offers insights into the emerging uses and imaginaries attached to the district, while also showing the resilience and adaptation of port legacies.
\end{abstract}

\section{Keywords}

imaginaries; innovation ecosystem; maker movement; port-city interface; Rotterdam; transition; waterfront

\section{Issue}

This article is part of the issue "Planning for Porosity: Exploring Port City Development through the Lens of Boundaries and Flows" edited by Carola Hein (Delft University of Technology, The Netherlands).

(C) 2021 by the authors; licensee Cogitatio (Lisbon, Portugal). This article is licensed under a Creative Commons Attribution 4.0 International License (CC BY).

\section{Introduction}

Port-cities hold a special place in urban planning, due not just to their topological positioning at the boundary of sea and land, but also to the socio-technical transition challenges they have been-and continue to bepresented with. The port-city interface, that is the spatial, social, and economic overlap of port and urban functions (Hesse, 2018), has changed drastically in the last century. The changing port-city interface offers a vantage point from which to observe post-industrial dynamics and processes of reindustrialization, and to assess the extent to which they provide more locally embedded and socially inclusive forms of economic development (Grodach \& Gibson, 2019). In this optic, waterfront regeneration projects, accelerated in recent decades by the desire to attract creatives and knowledge workers and accrue socio-economic gains, have given new purposes to areas where functional port activities were in retreat-yet they have often been coupled with controversial outcomes 
and concerns over commercialization, marginalization of communities, and standardization of uses (Jones, 2017; Smith \& Garcia Ferrari, 2012). More recently, imperatives relating to decarbonization, digitalization, and the circular economy have set new challenges and opportunities for port-cities, changing spatial demands and adaptation needs for businesses and city planners (Gladek et al., 2018; Van den Berghe \& Vos, 2019).

In the port-city of Rotterdam, the neighbourhoods designated under the umbrella term 'Rotterdam Makers District' offer a prime location from which to explore how the port-city interface is evolving, and how the city is regenerating its waterfront while also approaching a return of manufacturing to the city. In fact, the creation of this district in 2018 is closely interlinked with the recent history of the changing relationship between port and city. Historically in use as bustling trade, storage, and ship yarding nodes of the city's port activities, the Makers District is part of the second wave of urban redevelopment of the city of Rotterdam which kicked off in the early 2000s (Aarts et al., 2012). Figure 1 shows a map of the area and its location in the port-city of Rotterdam. At the turn of the millennium, technological advancements made it possible to move many port-related activities out of the area and farther out of the city, gradually hollowing out these harbors' port-related economic foundations and opening opportunities for new uses of the area.

As with many areas that experienced a retreat of port activities, "becoming ghost districts, challenges to urban development" (Hein, 2016, p. 429), similarly this district did not just lose its livelihood, but in part its sense of seaport identity (Kermani et al., 2020). Today, the Makers District redevelopment is coupled with 'imaginaries' (Jessop, 2012) defined as frames that capture actual and aspirational accounts of the area's transformation. In the case of the Makers District, such imaginaries capture an area striving to become the heart of innovative manufacturing industry in the city (Port of Rotterdam, 2018). Moreover, both areas fit into the CityPorts' vision of incorporating a role for the creative class "as pioneers who acknowledge the quality

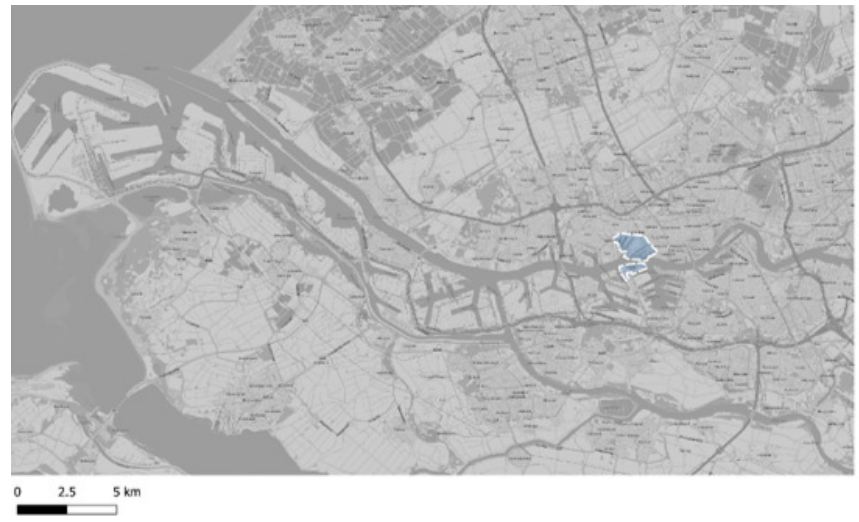

of a newly developed area or characteristic heritage site" (Ontwikkelingsmaatschappij Stadshavens NV, 2005, p. 82; see also Stadshavens Rotterdam, 2009). Yet the two neighbourhoods within the Makers District display variations in their imaginaries. While Merwe Vierhavens $(\mathrm{M} 4 \mathrm{H})$ is home to "pioneering and artisanal manufacturing firms...creative entrepreneurs and companies in the eco-manufacturing industry", Rotterdamsche Droogdok Maatschappij (RDM) is the "hotspot for innovation in the port" (Rotterdam Makers District, 2021a, 2021b). As the area vision and its implementation unfold in the area, the maritime identity and water-related heritage values have been highlighted as important connectors in urban renewal and redevelopment (Kermani et al., 2020).

In this article, we explore how old and new functions and jobs have evolved in the area now designated as Rotterdam Makers District, in order to gain insights into port-city transitions and the 'purposive adaptation' (Tomlinson \& Branston, 2014) of the former maritime cluster, whereby we show how the area has adapted to exogenous change (in particular, the decline of traditional port activities) and diversified its profile, including sectors with higher urban value. In so doing, we assess how the evolution of jobs aligns with fulfilling the policy imaginaries for the area. Few studies have integrated the study of port transitions at the level of spatial claims on space, but also imaginaries of the future (see Grodach \& Gibson, 2019). The Makers District offers a unique setting for a fine-grained analysis of transitions on the ground, from the perspective of uses, flows, and imaginaries. This leads us to the following research questions: To what extent have the boundaries between the city and the port become more porous in the area designated as Rotterdam's Makers District in terms of its spatial function and the flow of port and creative industry users? And how do old and new users relate to imaginaries of the district?

In what follows, we first map the field of extant research on port-city transitions. We then set out the empirical approach that has guided us in this investigation. Finally, we report on the results of our analysis. The article offers a longitudinal and contemporary

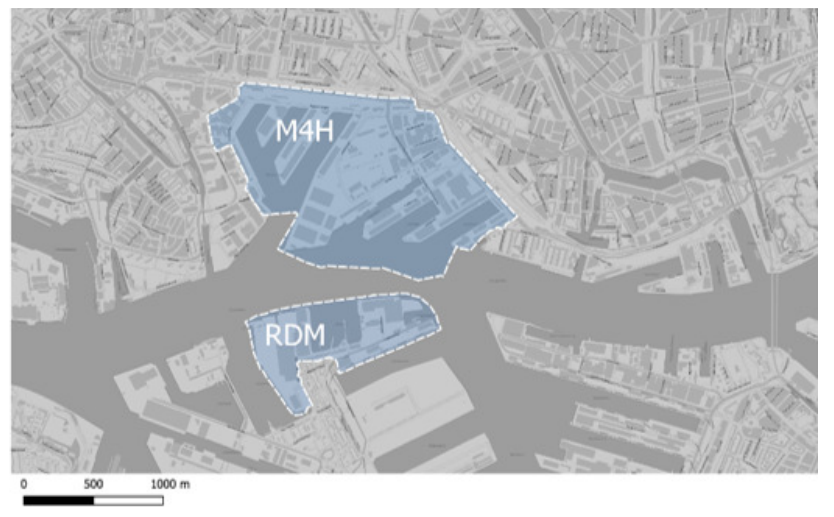

Figure 1. Rotterdam Makers District, located to the West of the city centre. The port industrial activities have expanded westwards. Source: Figure by Erasmus UPT (2020), based on Publieke Dienstverlening op de Kaart (2021). 
snapshot of current business occupants of the district. The results support the relevance of the conceptual lens of porosity in urban planning (Wolfrum, 2018), insofar as they show that the area's transition can be typified by the withdrawal of certain (port) activities, the persistence and innovation of others, and the arrival of new activities and users. The article contributes to existing literature that calls for a paradigm shift in waterfront regeneration, aligning it to a more progressive and longterm planning agenda calling for more socially responsible change (Jones, 2017; Stouten, 2017). Moreover, the article offers novel data to substantiate the interconnections of policy vision, legacy of the area's former uses, and new embodiments.

\section{Literature Review}

The relation between port and city has been the subject of numerous strands of research over the last forty years. In particular, the evolution of ports has drawn attention to their implications on urban development, decline, and reinvention-and to the underlying competition or cooperation between port and city (see Witte et al., 2018). We can distinguish three main contributions.

Firstly, the relation between port and city has been the subject of research into integration of functions and the potential conflicts which may arise from oppositional claims for space (Daamen \& Vries, 2013; De Langen, 2006; Dooms et al., 2013; Parola \& Maugeri, 2013). Such studies have drawn attention to the underlying tensions between the port as an economic engine, and the impact of its externalities on the larger region, not least environmental impacts on noise and pollution levels, and societal impacts on neighbouring communities (see Hein, 2016). Moreover, it raises the attention to the growing complexity and diversity of the stakeholder interests at play in port-city interfaces. Research has looked at how industrial and residential land-uses can be combined, highlighting the complexities of pursuing an innovation agenda and attracting high-skilled knowledge workers, while also giving space to a diverse economic base including urban manufacturing (Grodach \& Gibson, 2019; see also Hill et al., 2018; Hill et al., 2020). Such tensions play out against the background of a renewed optimism in relation to entrepreneurial activities engaging in smallscale urban manufacturing that combines design and production-often referred to as the 'maker movement' (Hatch, 2013; Wolf-Powers et al., 2017). The movement is spurred on by changes in consumption patterns and a growing demand for customized items that are smallbatch, locally sourced and produced (Hirshberg et al., 2017). Making constitutes a strong component of the imaginary of the Makers District, this research will thus show how and in what ways it has become an integral part of the area's development.

A second strand of research emerged from the notion of port-cities as ecosystems (Hayuth, 1982; Jansen, 2020; Witte et al., 2018). In this ecosystem approach, stake- holders and institutions in the port city strive to reconcile economic and societal values, in a sustainable way. In this perspective, clusters of economic activities are often based on collaborative action and shared value creation (Jansen, 2020). Recent policy strategies in Rotterdam have sought to enable the emergence of an innovative ecosystem in former port areas, for example through acceleration programmes for port-related start-ups and in refurbishing industrial heritage buildings into combined infrastructure of incubators, test facilities, and shared working space (Witte et al., 2018). Improvements to the quality of life in the city "became necessary to seek high-level headquarters and a high-quality labour pool" (OECD, 2013, p. 86). Our analysis therefore seeks to explore how the notion of innovative ecosystem applies to the area, exploring the collaborative spaces that are present in the area and the types of emerging activities they host.

Thirdly, and connected to the quality-of-life dimension just mentioned, the port-city interface has been the focus of research on waterfront redevelopment and revitalization (Bird, 1963; Daamen \& De Vries, 2013; Hoyle, 1989, 2000; Wiegmans \& Louw, 2011). Taking a historical perspective offers insights into the spatial evolution of the relation of port and city: Subsequent phases of expansion and shrinkage, leaving behind port wastelands, are closely connected to logistic and technical developments in port processes and activities (Hoyle, 1989; Kokot, 2015). Maritime identities faded as port and city moved away from one another, and as urban functions started to move into disused port areas on the waterfront near the city (Gordon, 1996; Hein, 2016). Particularly since the 1980s, the revitalization of waterfront areas, marginalized by the moving out of port activities, has often set in motion processes of gentrification, characterized by the upward mobility of land use values and the subsequent social displacement and exclusion of former residents (Lees, 2000). In the resulting port-city relations, while the pace of port expansion is seen as slowing down, urban uses and functions have moved in (Wiegmans \& Louw, 2011). In Rotterdam, a number of former port and industrial areas have become refashioned as higher-end areas of consumption (Doucet et al., 2011). Moreover, scholarship has shown how waterfront districts and harbour areas are particularly appealing to creative and knowledge workers, for whom the distinctive 'look and feel' of the neighbourhood in which they chose to locate can pay dividends in terms of their own positioning in a competitive market (Smit, 2011). We thus seek to explore the new users of the area, exploring the profiles of creative and knowledge workers who have moved in, and emerging spaces of consumption.

Rotterdam's Makers District lends itself to an exploration of the port-city interface from these three perspectives. In doing so, we explore the reintegration of the area in the productive heart of the city. The research presented in this article is explorative in its ambition, using a combination of longitudinal quantitative and qualitative 
data on companies in the area. The aim is to explore the recent evolution of jobs in the area now designated as the Makers District and to compare current and past uses of the area, and to subsequently zoom into exemplar buildings and facilities. In so doing, we seek to trace the transition in uses, while assessing how observed trends fit within the changing port-city interface, and align with policy aspirations and visions.

\section{Methodology}

In this article, we seek to explore the flow of port and creative industry users in/out of the area, and to see how old and new users relate to the policy vision and imaginaries for the district. To address these questions, the researchers collected data of companies which have established in the area designated as Rotterdam Makers District, drawn from the Dutch LISA (2017) employment dataset. The information retrieved included the number of companies per sector, company address, and employees per year for a time series of 2000-2017. The timeframe captures the area's transition from the early policy vision (Ontwikkelingsmaatschappij Stadshavens NV, 2005) to the spatial planning vision (Municipality of Rotterdam and Port of Rotterdam Authority, 2011) and the creation of denomination of the Makers District in 2018. Data was restricted to postal codes, that capture the geographical boundaries of the Makers District: selected postcodes within NL-3029 for M4H and NL-3089 for RDM. To further demarcate the area, the researchers further selected only those companies that are located within the physical space of the Rotterdam Makers District, in line with urban planning policy documents by the municipality and port authority of Rotterdam. Based on the companies' standard business information (SBI) code from the Central Bureau of Statistics, we then classified them according to five categories. These categories allowed us to explore the transitions in the traditional port sector, while also exploring the extent to which the area's policy vision and imaginaries connected to creative sectors and manufacturing were fulfilled. The five categories are:

(1) Port-related: companies with the SBI codes covered by the Dutch Port Monitor (Erasmus UPT, 2020), the annual monitoring report published by Erasmus Centre for Urban, Ports and Transport Economics, commissioned by the Dutch Ministry of Infrastructure and Waterworks, which provides insights into the employment, business activity and added value of the Dutch seaports;

(2) Creative industries and (3) information and communication technology (ICT): for these two categories, we based our classification on the SBI codes used in the Monitor Creative Industry (Media Perspectives, 2019). For the ICT category, one SBI code (2790) is also included in the Port-related category, following the Dutch Port Monitor classification. Therefore, companies with this specific SBI code are considered Port and ICT related.

(4) Manufacturing (other): for this category, we used the 'Industry' SBI classification (Central Bureau of Statistics, 2008), excluding any sectors that were included in the port or creative industries categories above. This provides a list of SBIs that we considered as Manufacturing (other).

(5) Other: the remaining companies were combined in the category 'other,' which includes the other sectors, such as wholesale (other), retail, car repair and maintenance, and education.

Location quotients were calculated for the five categories and two areas encompassed within the Rotterdam Makers District (RDM and M4H), exploring their evolution over the time period 2000-2017. The two areas were considered separately, allowing for a more nuanced analysis of the sectoral similarities and differences over time, comparing them to the wider Rijnmond region. The location quotient measures the concentration of a particular business sector, clusters, or category of economic activities, relative to the concentration of the same industry at a regional or national level. For example, we can use these measurements to see how the port clusters evolved in comparison with the rest of the Rijnmond region. By exploring relative measures of concentration of particular sectors over time, we can assess to what extent new economic sectors have blended in with typical port functions that have traditionally occupied the waterfront areas.

Complementary to the longitudinal data, the researchers collected qualitative data on a sample of 216 companies currently located in the district. The data was collected via the websites of RDM, M4H Makers District, makerspaces within the area (e.g., Keilewerf), as well as company websites and profiles on LinkedIn. Data collection was also complemented by several visits to the area, to identify any companies not included in the abovementioned sources. We compiled the information in a single database, structured according to the following information: name, address, date of establishment, company size, facility used, sector of activity, tag line, and 'about' and/or mission statement of a company. We then created word clouds using the taglines used by companies in our database, to explore prominent themes and activities per area, allowing us to compare the predominant features of the $\mathrm{M} 4 \mathrm{H}$ and RDM. We then zoomed into some of the areas' iconic locations, exploring their contemporary uses. In addition to the quantitative data, this more qualitative approach allowed us to explore the extent to which the companies located in these areas and particular buildings fit within the imaginaries and policy visions for the Makers District. 


\section{Findings}

\subsection{A Makers District in the Making}

The Makers District falls within the remit of the Rotterdam CityPorts Development Company (Ontwikkelingsmaatschappij Stadshavens NV, 2005), set up in 2004 by the Rotterdam municipality and the port authority with the goal of regenerating the area through a mixed-use strategy (Ministry of Infrastructure and Water Management, 2010). The CityPorts spreads over 1,500 hectares $(1,000$ land, 500 water area), situated on both sides of the Maas river, between the main port in the west, the Delft delta technology in the north, and the Rotterdam city centre nearby in the east. It consists of four distinct port areas: Waalhaven and Eemhaven on the south bank, Merwehaven and Vierhavens on the north bank. The Rotterdam CityPorts Development Company was tasked with organising and realising the transformation of the city port into a sus- tainable combination of port and urban functions, reaping the economies of scale of accelerated shipping, while also addressing growing demands for space for urban economic activities and housing. The strategy was based on a strong relationship between both city and port developers, reflected in the CityPorts cooperative governance model, which operates as a limited company with $50 \%$ shares for the Port of Rotterdam Authority and Municipality Rotterdam.

Within the CityPorts' transformation started at the turn of the millennium, the Makers District materializes the city's ambitions to meet the challenges of the new economy, developing a testing ground for futureproof innovative technical entrepreneurship and innovative manufacturing (see Table 1 for a timeline of the area). A former shipyard, the redevelopment of RDM was intended to focus on new, small enterprises in the sectors of education, culture, and leisure, maintaining of its neighbouring areas - the Heijsehaven-as an "Urban Shipyard" (Ontwikkelingsmaatschappij Stadshavens NV,

Table 1. Timeline of key events in the area currently designated as Rotterdam Makers District.

\begin{tabular}{|c|c|c|}
\hline Time & Scope & Milestone \\
\hline 1902-1996 & RDM & At shipyard RDM, 355 seagoing ships were built, of which 18 submarines \\
\hline 2002 & RDM & $\begin{array}{l}\text { City Council decides to acquire RDM-site and hand-over exploitation to Municipal Port } \\
\text { Authority Rotterdam }\end{array}$ \\
\hline 2002 & RDM & Albeda College takes over company school from RDM \\
\hline 2004 & RDM & $\begin{array}{l}\text { Corporatisation of Port of Rotterdam Authority, RDM-site tran[3pt]sferred to Port of Rotterdan } \\
\text { Authority }\end{array}$ \\
\hline 2004 & $\mathrm{RDM} / \mathrm{M} 4 \mathrm{H}$ & $\begin{array}{l}\text { Rotterdam CityPorts Development Company formally founded with aim to transform } \\
\text { CltyPorts area }\end{array}$ \\
\hline 2007 & RDM & $\begin{array}{l}\text { Renovation of RDM engine room factory, by founding partners Port of Rotterdam Albeda } \\
\text { College, Rotterdam University of Applied Sciences }\end{array}$ \\
\hline 2008 & $\mathrm{M} 4 \mathrm{H}$ & Opening of renovated Vertrekhal Oranjelijn as collective building for creatives \\
\hline 2009 & RDM & $\begin{array}{l}\text { Innovation Dock in use for education by Albeda College and Rotterdam University of Applied } \\
\text { Sciences }\end{array}$ \\
\hline 2009 & RDM & Official opening Innovation Dock and Dry dock and former RDM headquarters \\
\hline 2012 & $\mathrm{M} 4 \mathrm{H}$ & Erasmus Centre for Entrepreneurship established in Rotterdam Science Tower at $\mathrm{M} 4 \mathrm{H}$ \\
\hline 2013 & RDM & RDM Centre of Expertise learning community launched \\
\hline 2014 & $\mathrm{M} 4 \mathrm{H}$ & Opening Central Storehouse, as Innovation Centre for Sustainable Construction \\
\hline 2014 & $\mathrm{RDM} / \mathrm{M} 4 \mathrm{H}$ & Publication of the Maakstad Rotterdam by the municipality of Rotterdam \\
\hline 2014 & $\mathrm{M} 4 \mathrm{H}$ & Start of Keilewerf initiative \\
\hline 2015 & RDM & Opening Submarine dock \\
\hline 2015 & RDM & Brand name RDM Rotterdam, which comprise RDM Business, RDM Campus and RDM Events \\
\hline 2017 & $\mathrm{M} 4 \mathrm{H}$ & Opening Keilewerf II \\
\hline 2018 & RDM & $\begin{array}{l}\text { Partnership agreement signed between Port of Rotterdam, Rotterdam University of Applied } \\
\text { Sciences and Technical College Rotterdam }\end{array}$ \\
\hline 2018 & $\mathrm{RDM} / \mathrm{M} 4 \mathrm{H}$ & RDM Rotterdam and M4H form Rotterdam Makers District \\
\hline 2019 & $\mathrm{M} 4 \mathrm{H}$ & Municipality and Port Authority set out the spatial framework for $\mathrm{M} 4 \mathrm{H}$ \\
\hline 2020 & $\mathrm{RDM} / \mathrm{M} 4 \mathrm{H}$ & Community Platform Rotterdam Makers District launched \\
\hline
\end{tabular}

Source: Rotterdam Makers District (2021a, 2021b). 
2005). Industrial heritage and characteristic port constructions would be made available for temporary or permanent spaces for start-ups, creatives, restaurants. On the other side of the river, the $\mathrm{M} 4 \mathrm{H}$ port basins were developed in the 1930s for breakbulk cargo (mainly fruit and vegetables) which were handled with conventional cranes and manpower. Up until the 1990s the area was a bustling port area, but gradually these perishable goods began to be shipped in temperature-controlled 'reefer' containers, leading to a shift of port activities to container terminals elsewhere in the port.

Following this historical overview, we now turn to the findings derived from the analysis of location quotients of sectoral employment in the two areas of the Makers District, drawn from the LISA (2017) dataset (for the period 2000-2017, exploring the historic evolution of the area's profile). The findings are presented in Figures 2 and 3 . The figures offer an overview of the location quotients for five sectors: Port, Creative, ICT, Manufacturing (other), and Other.
The location quotient by number of jobs for the $\mathrm{M} 4 \mathrm{H}$ area point towards a number of trends (see also accompanying map in Figure 4). First, we see a relative decline in port-related jobs compared to the wider region (from over 2,5 times the regional average to just under 2). The number of port companies has also decreased. The type of port jobs also changed: We see a decline in engineering and technical port-related jobs, cargo and fruit and vegetable handling and support activities for water transport, while handling in drinks, and manufacturing of chocolate and sugar confectionary remain stable or grow. In 2004, while $\mathrm{M} 4 \mathrm{H}$ was still a logistics hub for handling of fruit and juices, the Port of Rotterdam presented plans to gradually move this cluster of companies to the south side of the river, at WaalhavenEemhaven. Indeed, facilities in the area were no longer deemed suited to particular trade functions, resulting in rising building disuse, area decline and impoverishment, and ensuing problems of social marginalisation. The area's decline was exacerbated by road and railway

\section{Location Quotient - Jobs (M4H-RIJNMOND)}

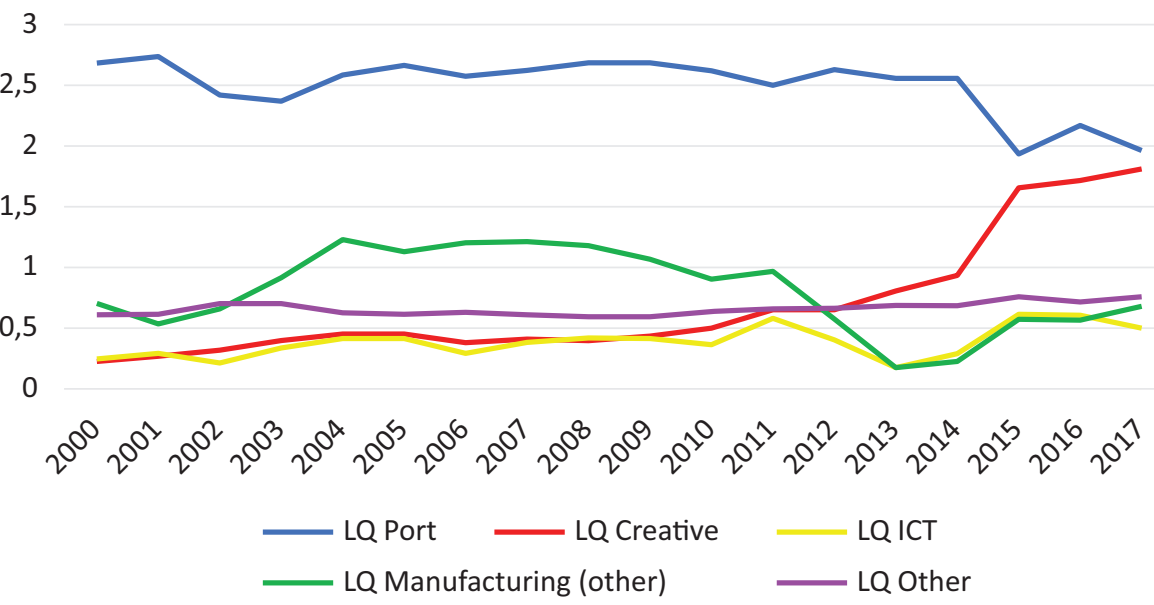

Figure 2. Location quotient results for M4H by sector classification. Source: LISA (2017; data from 2000-2017).

Location Quotient - Jobs (RDM-RIJNMOND)

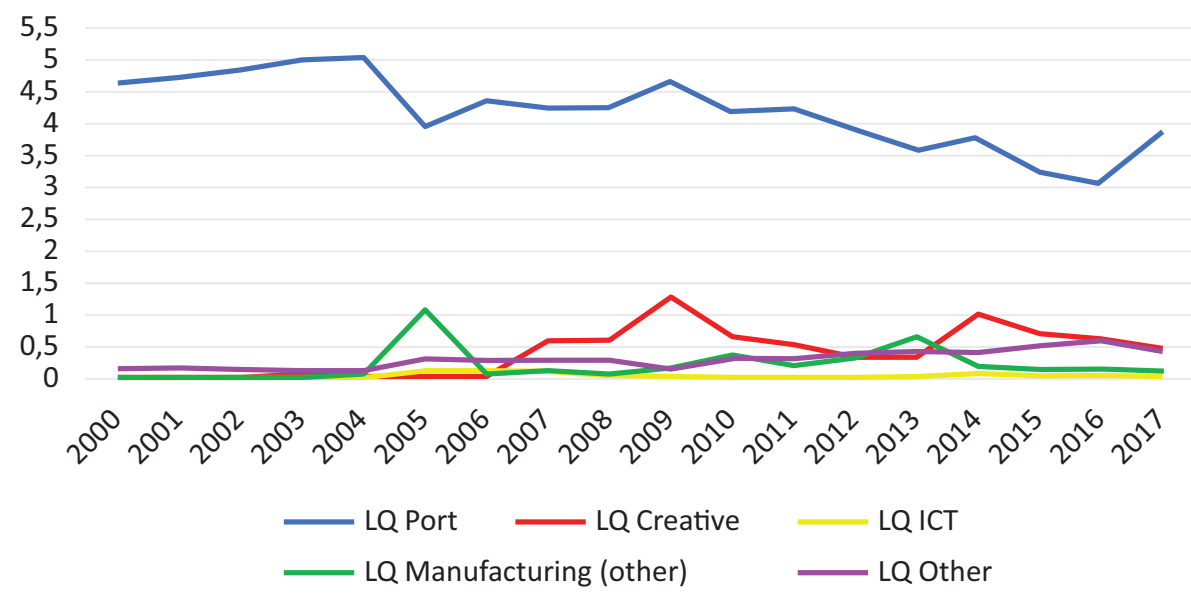

Figure 3. Location quotient results for RDM by sector classification. Source: LISA (2017; data from 2000-2017). 
Year 2000

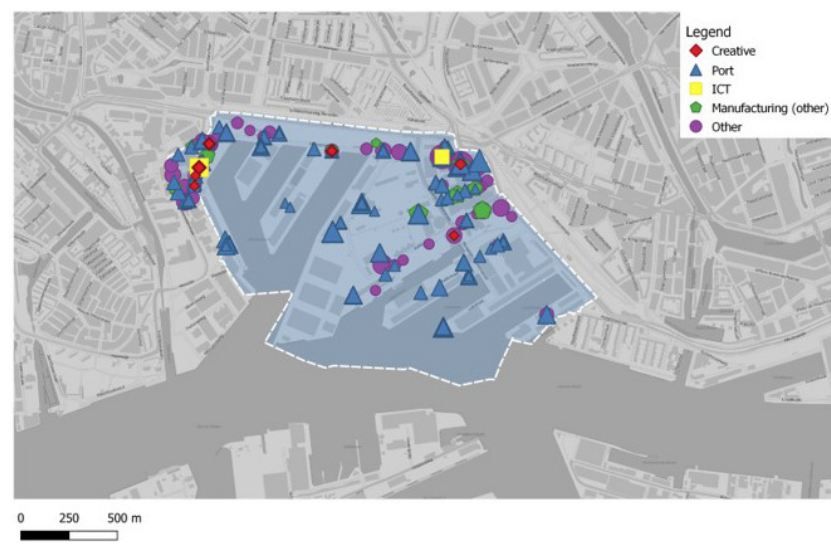

Year 2010

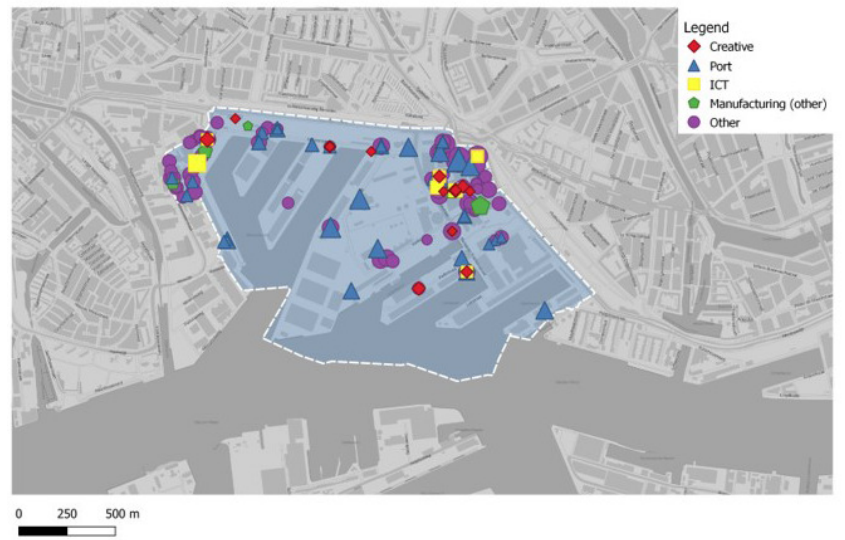

Year 2005

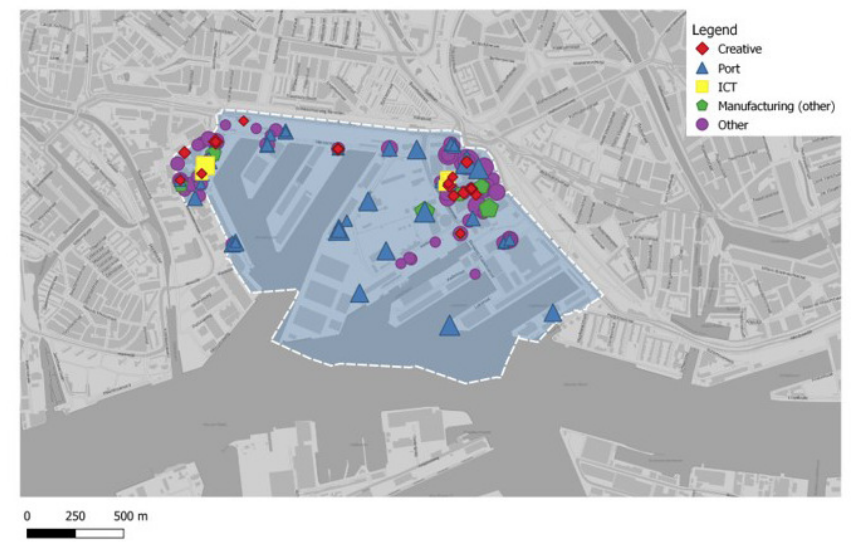

Year 2017

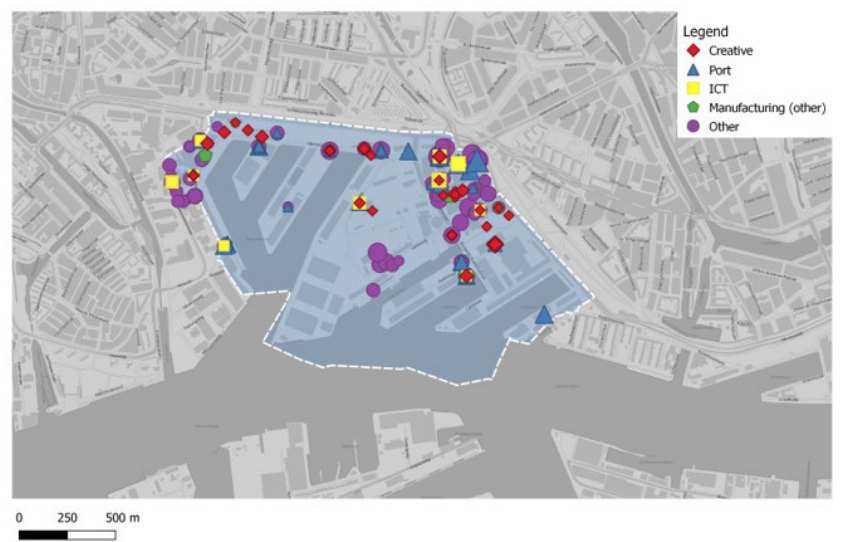

Figure 4. Companies in M4H by sector, 2000-2017. The symbol size represents the number of jobs. Source: Figure by Erasmus UPT (2020), based on LISA (2017) and Publieke Dienstverlening op de Kaart (2021).

infrastructure barriers causing heavy traffic which separated it from the rest of the city-however, it was transformed in 2014 into a shopping mall with a rooftop park and citizen driven communal garden.

In the manufacturing category, which comprises manufacturing jobs that are not port or creative industry related, we see an alternation of growth, decline, and revival-yet generally the concentration of jobs in these manufacturing sectors, as well as in the 'Other' category, do not diverge greatly from the regional profile. The number of 'manufacturing other' companies shows a small increase-notably in the manufacturing of furniture, interior construction, and manufacture of business furniture, but also food processing (bread and fresh pastry) and medical instruments. In the 'Other' category, we see a decline in municipality services (housing, civil works) and non-life insurance, and an increase in jobs in secondary vocational education and adult education, medical services, and justice and judicial activities. In 2015, the Erasmus Centre of Entrepreneurship moved into the Science Tower in $\mathrm{M} 4 \mathrm{H}$, establishing itself as an open and collaborative education and innovation setting. Moreover, the area is characterized by a relatively stable number of jobs in retail selling do-it-yourself articles and equipment-which connects to the area's maker profile.
The trend is different for the creative industries though, where we see a location quotient increasing from 0,23 to 1,79 which shows an increasing concentration of creative jobs relative to the profile of the Rijnmond region. Creative industries were identified as important pillars of urban economic growth in the early stages of the redevelopment (see Rotterdam Development Strategy, 2005); while the M4H area plan for 2009 identified how "creative pioneers, entrepreneurs and developers" had set their sites on the area, symbolizing the initial stages of an accelerating area metamorphosis (Stadshavens Rotterdam, 2009 , p. 17). Compared to the region, the area has become attractive in attracting companies and related jobs since 2014 shared facilities for creatives, such as the Keilewerf, were launched. In 2017, M4H attracted almost twice as many creative jobs compared to the rest of Rijnmond-region. Notably, we see an increase in jobs in architecture, writing, graphic design, industrial and product design, and marketing and advertisement. Jobs in new creative sectors also appear, for instance motion picture and TV programme production and support activities for the performing arts. The ICT category is less concentrated in $\mathrm{M} 4 \mathrm{H}$ compared to the Rijnmond region (0,5 times), with some upward trends in writing, 
producing and publishing of software, webportals, and computer consultancy and support, while printing activities are in decline. The number of jobs remained relatively stable in the period 2000-2017, while the number of companies increased. Looking ahead, between 3,500 and 5,000 new homes are planned in the area by 2035 (Programmabureau Rotterdam Makers District, 2019), ideally blending in with creative industries, makers, and urban services facilities in an "versatile living-andworking environment" (Programmabureau Rotterdam Makers District, 2019, p. 4). The area foresees a mixed crowd of young urban professionals, entrepreneurs, residents, city farmers, and visitors, coming together in a test bed of the circular economy (Programmabureau Rotterdam Makers District, 2019).

Our analysis of job evolution in the RDM area shows a different trend compared to $\mathrm{M} 4 \mathrm{H}$ (see Figure 3 and map in Figure 5). In the early 2000s, the area had a strong maritime profile, with around five times the number of jobs in port-related sectors compared to the rest of the region. This concentration of jobs has declined slightly over the period of observation (from 4,6 in 2000 to 3,5 times the regional average in 2016), but remains strong. Meanwhile, the number of port-related companies increased in the period 2000-2017 (from 16 to
21 companies). Yet within this category we see a change in the types of sectors over time; most notable is the decline of jobs in the ship building industry. Jobs in wholesale of chemical products, fuels, and other mineral materials have also left the area. Cargo handling, warehousing and storage, freight forwarding, and ship's agents remain rather stable, while we see a growth in support activities for water transport (heavy lift, mooring activities), and wholesale articles for ships and fishing. Engineers and other technical design and consultancy area are also in the area.

The area has a relatively limited creative industry profile, with the exception of architecture firms and a foundation supporting sustainable housing. In ICTs we found jobs in writing, producing and publishing software, and manufacture of other electrical equipment-yet the number of jobs and companies are marginal. It should be noted that jobs relating to artificial intelligence, loT, and additive manufacturing that are present in the area fall within other categories, notably manufacturing or 'other' (e.g., loT under education). In the 'manufacturing (other)' category there is a furniture maker. In the 'other' category, we see a growth in non-university higher education and other (vocational) education institutions and related services, including business education and
Year 2000

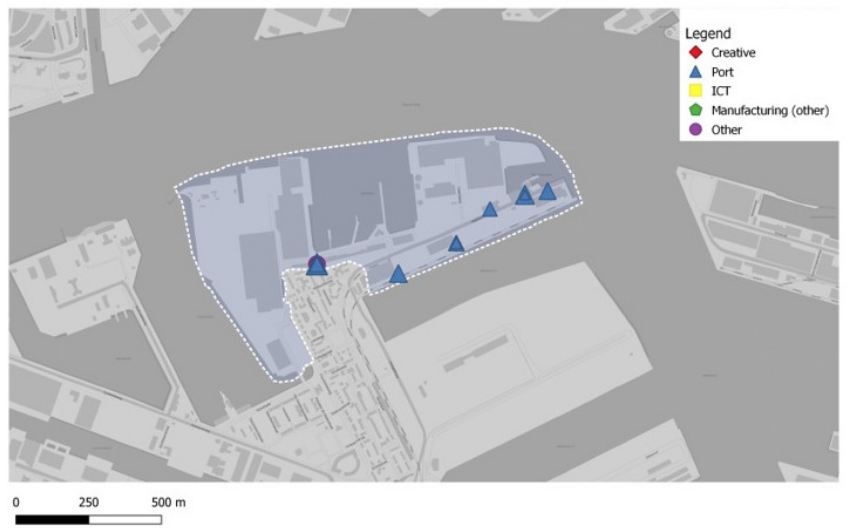

Year 2010

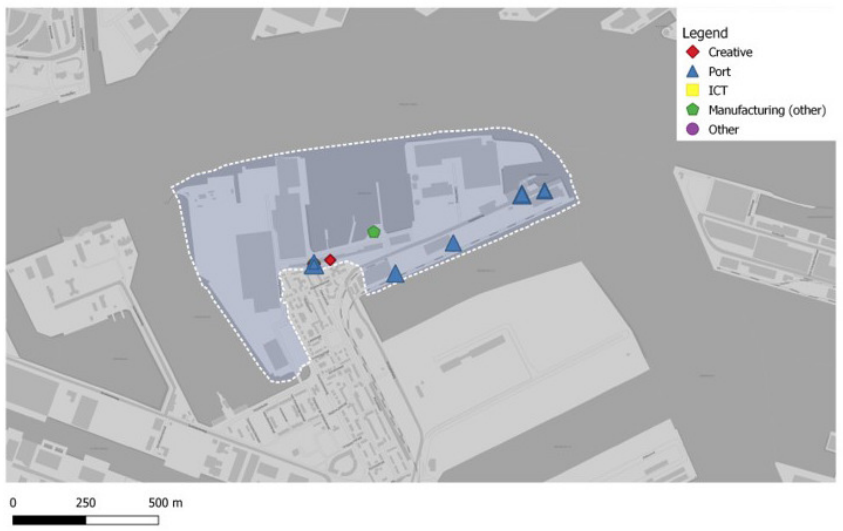

Year 2005

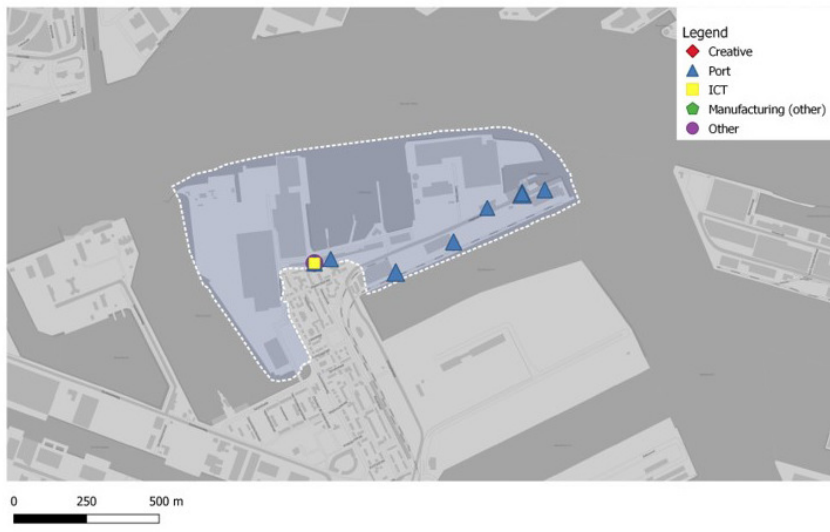

Year 2017

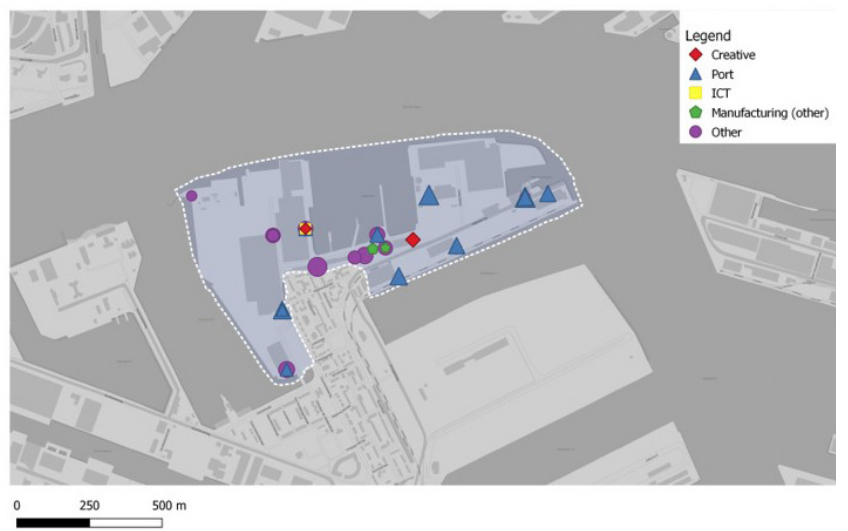

Figure 5. Companies in RDM by sector, 2000-2017. The symbol size represents the number of jobs. Source: Figure by Erasmus UPT (2020), based on LISA (2017) and Publieke Dienstverlening op de Kaart (2021). 
training. Indeed, the collaboration between Rotterdam University of Applied Sciences and Albeda College in 2007 was the start of the education campus at RDM. With its arrival, RDM gained a campus for technical vocational and higher education in the domains of mechanical engineering. In 2005, Rotterdam University of Applied Sciences set up a joint venture with the Shipping and Transport College for nautical education. This collaboration was strengthened in 2011 with the establishment of the Rotterdam Mainport Institute, which in turn gave a strong impulse to the learning community Center of Expertise 'Sustainable Mainport Innovation.' The RDM Center of Expertise offers modern 'context-rich' learning environments, where experimentation at the crossroads of education, research, and business is stimulated. Apart from this strong focus on education, the 'Other' category shows some dynamism in the area, with many new types of activities appearing in the area in the period 2014-2017, for example management and business consultancies and employment agencies. In this category we also see the phasing out of certain wholesale and road freight transport activities.

\subsection{Urban Experimentation in Old Buildings}

In her seminal work The Death and Life of Great American Cities, Jacobs (1961/1992) purported that innovative ideas require old buildings to thrive; innovative ideas are risky, and new, dedicated facilities would enhance that risk. This dynamic is seen as at the heart of artist-led urban regeneration of dilapidated and rundown neighbourhoods. Urban experiments need "a good lot of plain, ordinary, low-value old buildings, including some rundown old buildings" (Jacobs, 1961/1992, p. 187). In the Makers District, we see Jacobs' inkling in action: disused, wharf buildings are populated by new users, who give the spaces new purposes and functionalities, often with a collaborative ethos.

An analysis of the taglines of companies located in the Makers District in 2021 sheds further light on the transition the area is undergoing (see Figures 6 and 7). The making ethos of the area translates in frequent words such as design, make, work-which are common across the two areas. Zooming in on $\mathrm{M} 4 \mathrm{H}$, other frequent words include reference to work settings such as stu-

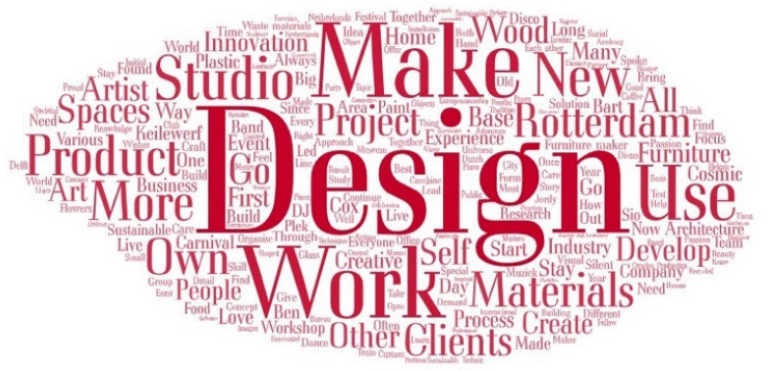

Figure 6. Word cloud derived from $\mathrm{M} 4 \mathrm{H}$ company taglines. dio and workshops, materials including wood and plastic, and product and projects, from furniture to art. In RDM, business and economic sector-oriented terms are more frequent, such as company, market, service, and industry. Innovation and training are also frequent, while port and offshore connect more clearly to the area's past. To take a closer look at the profiles of current occupants of the area, we zoom into some of the key facilities with a distinctive profile in the district. We provide a review of their past and present uses, including creative practices and urban manufacturing and connection to the port or urban functions (see Table 2 for a full overview).

The Keilewerf complex is situated in $\mathrm{M} 4 \mathrm{H}$ and is constituted of two separate buildings (Keilewerf I and II), totalling 6,000 $\mathrm{m} 2$ and around 80 entrepreneurs. The Keilewerf was opened in 2014 in an empty wharf, while the second was added in 2016. With the tagline "The wharf where you can make anything/have anything made," it is a complex where creative start-ups and entrepreneurs cluster and converge around shared spaces, facilities and equipment. A 2019 publication presenting the Keilewerf and its history shows wide array of almost 300 'werfers,' some of whom have moved to other premises and workspaces (Van den Berg et al., 2019). Their profile is relatively young (predominantly in the 25-35 age group) one-person companies (Van den Berg et al., 2019). Moreover, these makers work with traditional tools but also with 3D-printers, laser, and CNC machines. The buildings are rented from the municipality and plans to demolish them after 2021, to make way for new buildings, are temporarily postponed. In Keilewerf, the port legacy is least tangible. Indeed, none of the new users maintain a connection with more traditional port activities - with the possible exception of companies active in food production, given the area's fruit-handling activities. Most occupants can be characterized as a mix of designers and makers, some of whom have an orientation towards circularity. Most of its users are designers and producers, who prefer to work with (used) wood and metals, but also industrial designers and interior designers who have developed themselves into circular entrepreneurs. They build their concepts and products on passion for 'vintage' materials they use and turn it into something new. Users in this space also value transversal collaboration, social inclusion, creative design processes,

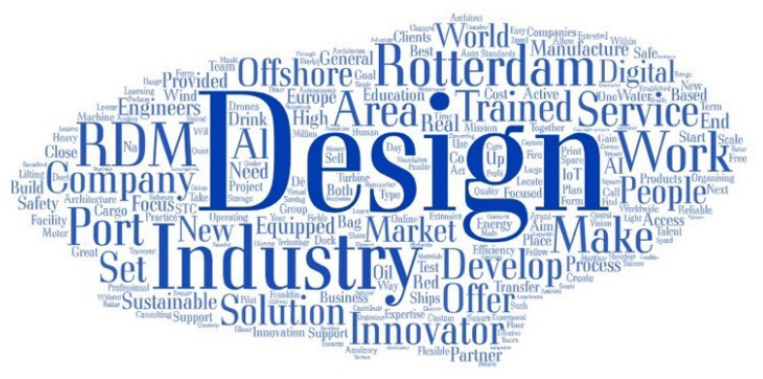

Figure 7. Word cloud derived from RDM company taglines. 
Table 2. Overview of users in Makers District key buildings.

\begin{tabular}{|c|c|c|c|}
\hline District & Building & Professions & Examples of company taglines \\
\hline $\mathrm{M} 4 \mathrm{H}$ & Keilewerf I & $\begin{array}{l}\text { Artists, } \\
\text { architects, } \\
\text { engineers, } \\
\text { designers, } \\
\text { software } \\
\text { engineers }\end{array}$ & $\begin{array}{l}\text { - "Design+Making" (Studio Met) } \\
\text { - "Artisan and contemporary" (Bink Meubel) } \\
\text { — "Interior design, vintage sales" (De Verbaasde Ree) } \\
\text { - "Hackerspace in Rotterdam" (Pixelbar) } \\
\text { - "Look and feel design" (Albert Potgieter Design) } \\
\text { — "Digital design and production" (Letolab) }\end{array}$ \\
\hline $\mathrm{M} 4 \mathrm{H}$ & Keilewerf II & $\begin{array}{l}\text { Artists, } \\
\text { architects, } \\
\text { industrial } \\
\text { designers, } \\
\text { manufacturers, } \\
\text { visual artists, } \\
\text { educators, } \\
\text { small retailers }\end{array}$ & $\begin{array}{l}\text { - "Electric navigation, silent, sustainable, carefree" (Taurus boats \& Tenders) } \\
\text { - "We. Design. Create. Work. Fix. Chaos" (We.Umbrella) } \\
\text { - "From the bottom of my city" (Bakkie Trots) } \\
\text { - "To understand the culture you must live it" (KAVVA) } \\
\text { - "Explorations in matter and space" (Studio Iwan Pol) } \\
\text { - "An iconic piece of Rotterdam at home" (The Talk of the Town) }\end{array}$ \\
\hline $\mathrm{M} 4 \mathrm{H}$ & $\begin{array}{l}\text { Rotterdam } \\
\text { Science } \\
\text { Tower }\end{array}$ & $\begin{array}{l}\text { Artists, } \\
\text { software } \\
\text { engineers, } \\
\text { industrial } \\
\text { designers }\end{array}$ & $\begin{array}{l}\text { - "The future of Maritime Innovation starts here" (PortXL) } \\
\text { - "All you need for a complete lab" (LabHotel) } \\
\text { — "We develop people in their entrepreneurial competences with the } \\
\text { academic knowledge and network of Erasmus University Rotterdam." } \\
\text { (Erasmus Centre for Entrepreneurship) }\end{array}$ \\
\hline $\mathrm{M} 4 \mathrm{H}$ & $\begin{array}{l}\text { Vertrekhal } \\
\text { Oranjelijn }\end{array}$ & $\begin{array}{l}\text { Architects, } \\
\text { engineers, } \\
\text { researchers, } \\
\text { software } \\
\text { engineers, } \\
\text { small retailers }\end{array}$ & $\begin{array}{l}\text { — "We design and develop meaningful and sustainable breakthrough } \\
\text { products" (Spark Design and Innovation) } \\
\text { _ "We partner with founders and companies to design and develop digital } \\
\text { products" (Awkward) } \\
\text { _ "Pure ingredients artisanal made" (Jordy's Bakery) } \\
\text { _ "Quality coffee in an iron packaging" (Santas Koffie) }\end{array}$ \\
\hline RDM & Dokloodsen & $\begin{array}{l}\text { Artists, } \\
\text { energy } \\
\text { engineers, } \\
\text { designers }\end{array}$ & $\begin{array}{l}\text { - "Creative, problem solving, innovative" (De Timmerij) } \\
\text { - "We raise awareness on renewable energy in an interactive, educative and } \\
\text { fun way" (Energy Floors) } \\
\text { — "The inspiration spot for architects and designers where aesthetics and } \\
\text { sustainability meet" (ICDUBO) } \\
\text { — "Designers and furniture makers" (Maatwerk Interieurs) }\end{array}$ \\
\hline RDM & $\begin{array}{l}\text { Innovation } \\
\text { Dock }\end{array}$ & $\begin{array}{l}\text { Software } \\
\text { engineers, } \\
\text { designers, } \\
\text { manufacturers, } \\
\text { educators }\end{array}$ & $\begin{array}{l}\text { - "Fuelling possibilities" (Arktura) } \\
\text { - "Challenging architecture" (Studio Rap) } \\
\text { - "Metal parts on demand" (Ramlab) } \\
\text { - "Provides sustainable 3D printing services and 3D printers in stone like, } \\
\text { durable and sustainable materials." (Concr3de) } \\
\text { — "Resilient realism. Sustainable building on water (Publek Domein } \\
\text { Architecten) } \\
\text { - "Innovative small wind turbines, ebike charging and distributed energy" } \\
\text { - "Leading in simulation and virtual solutions" (Vstep) } \\
\text { - "Boost your workforce and reduce risks of injuries using exoskeleton } \\
\text { solutions" (Skelex) } \\
\text { - "Making autonomous shipping a reality" (CaptainAI) } \\
\text { - "Aerial inspections and data engineering" (Dutch Drone Company) }\end{array}$ \\
\hline RDM & $\begin{array}{l}\text { Medische } \\
\text { Dienst }\end{array}$ & $\begin{array}{l}\text { Industrial } \\
\text { designers, } \\
\text { marketeers, } \\
\text { engineers }\end{array}$ & $\begin{array}{l}\text { - "Connects and renews the industry" (iTanks) } \\
\text { - "Pressure calculations for pipeline components and equipments" (Red-Bag) } \\
\text { - "The force is yours" (McNetiq) } \\
\text { - "Simply lifting high" (Tetrahedron) } \\
\text { - "Online marketing in the port of Rotterdam" (PortAble) } \\
\text { - "Lead generation marketing for the maritime industry" (Kelson) }\end{array}$ \\
\hline
\end{tabular}


Table 2. (Cont.) Overview of users in Makers District key buildings.

\begin{tabular}{llll}
\hline District & Building & Professions & Examples of company taglines \\
\hline RDM & Scheepsbouw & Marine & - "Your global partner for integrated rigging and mooring solutions" (Franklin \\
& loods & engineers, & Offshore) \\
& & educators & - "Largest technical vocational college in Rijnmond region" (Technical College \\
& & Rotterdam) \\
\hline
\end{tabular}

Notes: Dutch taglines have been translated into English by the authors. Information on the companies and taglines were drawn from area and company websites and Linkedln.

and contributing to an inclusive and sustainable society. The societal innovation component is also noticeable in the open character of some of the spaces, where publics of all ages are welcome for workshops for re-use and upcycling of construction materials (e.g., Buurman, De Bouwakademie). In addition to makers, Keilewerf I is also the place where you can find a higher number of artists compared to the other spaces. Keilewerf II is also an incubator for creatives. Companies here are relatively young (seven years on average). Keilewerf is home to a number of entrepreneurs who value sustainability, durability, and circularity. They use with a mix of materials: recycled plastics, textiles, glass, and use a variety of techniques from sculpturing, laser, and 3D printing. Other entrepreneurs have design studios, engaging in multidisciplinary work. Beyond the Keilewerf, $\mathrm{M} 4 \mathrm{H}$ houses numerous other companies that share a similar creative ethos and attention to social innovation and circularity. Some entrepreneurs are very explicit on their principles and strive for zero waste, a circular adaptive and sustainable society, clean air, water, and energy.

A historic and protected landmark in $\mathrm{M} 4 \mathrm{H}$ is the Vertrekhal Oranjelijn, with its rich history as location of Thomsen's stevedoring company. After decades of being disused, the municipality of Rotterdam acquired the building in 1990 and sold it again in 2003 to an entrepreneur with ambitions to set up a coffee roasting company. At present the building is a relatively small facility and has a similar profile to Keilewerf I and II, housing food companies, design, and architectural firms. The Erasmus Centre for Entrepreneurship is a key user of the Rotterdam Science Tower and has the ambition to support the development and acquisition of academic and entrepreneurial competences. The other high-profile tenant of the Science Tower is PortXL, an accelerator founded by the port of Rotterdam. PortXL offers facilities and opens up an ecosystem of investors and corporate partners to accelerate innovations in the port and maritime industry.

Of all the buildings in Rotterdam's Makers District, the Innovation Dock in RDM is possibly the most the 'port-related,' while also housing many relatively new companies. Compared to creative spaces in the $\mathrm{M} 4 \mathrm{H}$ district, the entrepreneurs at RDM are more into designing and developing concepts for industry. The products which are developed here are a mix of digital solutionsArtificial Intelligence for autonomous applications in (underwater) drones, internet of things technology, robotics-and innovative materials, e.g., by use of additive manufacturing. RDM also provides a base for innovative makers who have outgrown the phase of craftsmen or 'makers,' such as the scale up of Ampelmann and Franklin Offshore. Users of this space value sustainability and are keen to use computer and internet-based engineering to build their solutions. The building at Medische Dienst is a smaller space with a relatively strong port heritage. The building used to accommodate the shipyard's health services-but the only connection to its former use is now in its name (Medical Service building). Users of this space develop services and solutions for the port industry, often using web-based marketing, solutions, and software. The companies who find a workspace here have a connection with iTanks a network innovator with a strong network in the port industry. Core values are innovation, technology, solution-driven, and a strong focus on the port industry.

\section{Conclusions}

This article sought to answer the following research questions: To what extent have the boundaries between the city and the port become more porous in the area designated as Rotterdam's Makers District in terms of its spatial function and the flow of port and creative industry users? And how do old and new users relate to imaginaries of the district? To answer the questions, we relied on a combination of quantitative and qualitative dataset of companies, capturing the recent evolution of the area's economic profile. Our analysis of sectoral employment data from 2000 to 2017 (LISA, 2017) shows that the area's evolution can be typified a type of adaptation that combines the persistence of traditional port activities, the innovation of port activities, and the arrival of new activities and users, in particular new creative, manufacturing, and education profiles. Are we witnessing a porous port-city in the making, a carefully coordinated adaptive planning approach to blend in urban functions in former port areas? Indeed, the plans envision mixed use of spaces by a variety of users, but to what extent is it a deterministic process? Our data challenge the separation of port and city that has been hypothesised and modelled in the past (see, for instance, Bird, 1963; Charlier, 1992; Hoyle, 1989, 2000). Indeed, the Rotterdam Makers District as a waterfront area lends 
itself to an exploration of the tensions between and competition among port and urban uses (Daamen, 2007), revealing new forms of symbiosis and development.

Our data show that the port-city interface transition in Rotterdam is complex, and that even within a single port-city, distinctive trajectories can be found when zooming into specific former port neighbourhoods. The scale of retraction and redevelopment is also connected to the area's former uses, facilities, and the potential for reuse of skills and infrastructure. In RDM, the decline of traditional port sectors has given way to an innovative port industry, which protracts the area's significance in the regional port cluster. Meanwhile, $\mathrm{M} 4 \mathrm{H}$ rapidly rebrands itself as an urban makers' district, maintaining some links to its former past in produce handling. Our analysis of the occupants of the Makers District shows some differentiation between areas (RDM and $\mathrm{M} 4 \mathrm{H}$ ) and buildings within these areas in terms of their port and urban orientation. While in RDM the port-industrial and maritime legacy live on in the identity and sectoral orientation of numerous occupants (see also Kermani et al., 2020), in $\mathrm{M} 4 \mathrm{H}$ we find a clearer integration in the urban fabric of Rotterdam. In this area, we find that users project alternative imaginaries of the port-city, that are less anchored in its past and more oriented towards a more creative and socially innovative practices, including societally-engaged artistic expressions and small-scale manufacturing that is technologically advanced and often circular in its use of materials. This area is defined not just by its experimental approach, but also for new connections between education and business, collective learning, and shared practices - the social innovation element is stimulating a wider socio-cultural shift in the city, encouraging alternative consumption practices.

Overall, the Makers District in Rotterdam constitutes an ambitious and large-scale port-city waterfront planning redevelopment, striving to combine sustainable urban development with innovative manufacturing industries and creative entrepreneurship. At RDM, the integration is taking shape as aims and objectives of communities of practices integrate using the former shipyard buildings as spaces for technical vocational education, open spaces for experiments and innovation, often related to the maritime industry. The new partnerships between educational institutions are not only intended to adapt education to this age of rapidly advancing technology, but also to enable pathways for entrepreneurship, accelerating innovation and lifelong learning. The evolution also shows interventions by public authorities and actions by private actors are taking place simultaneously. Attractiveness is enhanced whenever refurbishing of buildings are finished, combined with marketing activities of carefully curated images set by port-city planners, but also by bottom-up initiatives by entrepreneurs themselves. The users gradually give the spaces new purposes, whereby the port industrial heritage buildings are the connectors between the old and new, giving home to new imaginaries and thereby supporting users in giving the areas new and authentic identities. The area's transition appears to align with the socio-economic imaginaries defined in strategic and policy documents setting out the area's development and ambitions.

The area embodies the city's ambition to promote the Next Economy paradigm (TIR Consulting Group, 2016), centred on collaborative, open, flexible production, enhanced by digitization and embedded in local value chains. Our qualitative analysis shows that regeneration strategies of Rotterdam Makers District to some extent embody what Jones (2017) describes as more socially responsible, innovative, entrepreneurial, and integrated regeneration objectives. Yet our data does not allow us to uncover whether such developments have the inclusive nature Jones (2017) advocates. The area's location and attractive character open up a dilemma for inclusive and progressive waterfront regeneration, as the new users contend with rising demands for urban space. In fact, the innovative and experimental nature of the area contends with pressure on the housing market, whereby the target for 3,500 to 5,000 new homes by 2040 is largely to be accommodated in former port areas (Hill et al., 2018). Some of the most vibrant and innovative collaborative spaces in the area, such as the Keilewerf I and II, are faced with an uncertain future in their current locations. The Rotterdam Makers District is often referred to as a testbed for innovation for a more circular and inclusive city. The real test will be whether the lessons learned here can lead to sustainable business and social innovation models that can both accommodate upscaling of manufacturing by the new makers while also accommodating diverse residents and uses in the area.

The article has some limitations, which future research should address. To begin with, our quantitative analysis of data on jobs and companies goes up to 2017, while our qualitative data is contemporary. Our data does not allow us to provide a quantitative analysis of employment from 2018. Secondly, while the categories we use to analyse the data allow us to explore sectors dynamics in the area, distinguishing between areas of activity that have been and are crucial to the area's development (port, creative industries, manufacturing, and ICT) they also mean that some of the numbers are too small to say something meaningful about particular sectors, for example ICT in RDM. Moreover, future analysis could also benefit from combining all manufacturing activities in one category (including port and creative industry-related manufacturing), to gain a clearer sense of the evolution of this sector in the area. Finally, future analysis would also benefit from the integration of land use data, allowing for deeper insights in the shifting 'urban housing frontier' in these centrally located waterfront areas (Wiegmans \& Louw, 2011). In this respect, the two areas of RDM and $\mathrm{M} 4 \mathrm{H}$ occupy very different positions in relation to the city centre, the former being farther afield, on the south side of the river Maas. 
A port-city transition is as complex as it is uncertain, especially because of the long-time horizon. We can argue whether the flexible, adaptive approach to make the transition of port-city waterfront redevelopment works better than a plan-led development (Daamen \& Louw, 2016), but by having a degree of urban porosity allows for a process of identity creation that builds on the port-city's past as well (Kermani et al., 2020). Moreover, it takes time to set the right conditions for a more heterogeneous category of urban industries vis-à-vis the former more homogeneous port logistics industries. This may suggest ambivalent plans and unclear approaches but accepting some degree of ambiguity can be good for new imaginaries to set root. This is especially needed when transition processes, systems, and multiple interlinkages between stakeholders and authorities are too complex to understand upfront. The art of creating new imaginaries is to collaboratively construct future realities for these port city areas where people are pulled in rather than pushed out.

\section{Acknowledgments}

The authors acknowledge the support of Jeroen van Haaren at Erasmus UPT for supporting the authors with data analysis and mapping. Maurice Jansen would like to thank the LDE PortCityFutures research programme for financial support. Amanda Brandellero acknowledges the support received by Dutch Research Council (project "Crafting future urban economies," grant number VI.VIDI.195.160).

\section{Conflict of Interests}

The authors declare no conflict of interests.

\section{References}

Aarts, M., Daamen, T. A., Huijs, M., \& de Vries, W. (2012). Port-city development in Rotterdam: A true love story. Urban-e, 2012(3), 1-28.

Bird, J. (1963). Seaports and seaport terminals. Hutchinson \& Co.

Central Bureau of Statistics. (2008). Standard industrial classifications (Dutch SBI 2008, NACE and ISIC), version 2018. Heerlen.

Charlier, J. (1992). The regeneration of old port areas for new port uses. In B. S. Hoyle \& D. A. Pinder (Eds.), City, capital and water (pp. 240-260). Routledge.

Daamen, T. A. (2007, June 25-28). Sustainable development of the European port-city interface [Paper presentation]. ENHR-Conference, Rotterdam, the Netherlands.

Daamen, T. A., \& Louw, E. (2016). The challenge of Dutch port-city interface. Tijdschrift voor Economische en Sociale Geografie, 107(5), 642-651.

Daamen, T. A., \& Vries, I. (2013). Governing the European port-city interface: Institutional impacts on spatial projects between city and port. Journal of Transport Geography, 27, 4-13.

De Langen, P. W. (2006). Chapter 20: Stakeholders, conflicting interests and governance in port clusters. Research in Transportation Economics, 17, 457-477.

Dooms, M., Verbeke, A., \& Haezendonck, E. (2013). Stakeholder management and path dependence in largescale transport infrastructure development: The port of Antwerp case (1960-2010). Journal of Transport Geography, 27, 14-25.

Doucet, B., van Kempen, R., \& van Weesep, J. (2011). Resident perceptions of flagship waterfront regeneration: The case of the Kop van Zuid in Rotterdam. Tijdschrift voor economische en sociale geografie, 102(2), 125-145.

Erasmus UPT. (2020). Havenmonitor 2020. De economische betekenis van Nederlandse zeehavens [Port monitor 2020. The economic significance of Dutch seaports].

Gladek, E., van Exter, P., Roemers, G., Schlueter, L., de Winter, J., Galle, N., \& Dufourmont, J. (2018). Circular Rotterdam; Opportunities for new jobs in a zero waste economy. Metabolic, Circle Economy, Blue City, Spring Associates.

Gordon, D. L. (1996). Planning, design and managing change in urban waterfront redevelopment. The Town Planning Review, 67(3), 261-290.

Grodach, C., \& Gibson, C. (2019). Advancing manufacturing? Blinkered visions in US and Australian urban policy. Urban Policy and Research, 37(3), 279-293.

Hatch, M. (2013). The maker movement manifesto: Rules for innovation in the new world of crafters, hackers, and tinkerers. McGraw Hill Professional.

Hayuth, Y. (1982). The port-urban interface: An area in transition. Area, 14(3), 219-224.

Hein, C. (2016). Port cities and urban waterfronts. WIREs Water, 3(3), 419-438. https://doi.org/10.1002/wat2. 1141

Hesse, M. (2018). Approaching the relational nature of the port-city interface in Europe: Ties and tensions between seaports and the urban. Tijdschrift voor Economische en Sociale Geografie, 109(2), 210-223.

Hill, A. V. (Ed.). (2020). Foundries of the future: A guide to 21st century cities of making. TU Delft Open.

Hill, A. V., Warden, J., Hausleitner, B., Muñoz Sanz, V., Meyer, H., Croxford, B., Domenech, T., Dellot, B., Wallace-Stephens, F., Vanin, F., Orban, A., Gobatto, F., Macron, A., Klapwijk, A., Nakhlé, L., \& Rebreanu, L. (2018). Cities of making: City report. Cities of Making.

Hirshberg, P., Dougherty, D., \& Kadanoff, M. (2017). Maker city: A practical guide for reinventing our cities. Maker Media Inc.

Hoyle, B. S. (1989). The port-city interface: Trends, problems and examples. Geoforum, 20(4), 429-435.

Hoyle, B. S. (2000). Global and local change on the port-city waterfront. Geographical Review, 90(3), 395-417.

Jacobs, J. (1992). The death and life of great American 
cities. Vintage Books. (Original work published 1961)

Jansen, M. (2020, June 10-13). Port innovation ecosystem, a symbiosis of capital [Online paper presentation]. IAME 2020 Conference "Sustainable Development of Shipping and Trade," Hong Kong, China.

Jessop, B. (2012). Economic and ecological crises: Green new deals and no-growth economies. Development, 55(1), 17-24.

Jones, A. L. (2017). Regenerating urban waterfrontsCreating better futures-From commercial and leisure market places to cultural quarters and innovation districts. Planning Practice \& Research, 32(3), 333-344. https://doi.org/10.1080/02697459. 2016.1222146

Kermani, A. A., van der Toorn Vrijthoff, W., \& Salek, A. (2020). The impact of planning reform on waterrelated heritage values and on recalling collective maritime identity of port cities: The case of Rotterdam. In C. Hein (Ed.), Adaptive strategies for water heritage (pp. 344-361). Springer. https://doi.org/ 10.1007/978-3-030-00268-8_18

Kokot, W. (2015). Port cities as areas of transition: Comparative ethnographic research. In W. Kokot, M. Gandelsman-Trier, K. Wildner, \& A. Wonneberger (Eds.), Port cities as areas of transition: Ethnographic perspectives (pp. 7-24). transcript Verlag.

Lees, L. (2000). A reappraisal of gentrification: Towards a 'geography of gentrification.' Progress in Human Geography, 24(3), 389-408.

LISA. (2017). LISA werkgelegenheid register van Nederland [LISA employment dataset of the Netherlands] [Data set]. https://www.lisadata.nl

Media Perspectives. (2019). Monitor Creatieve Industrie 2019 [Creative Industries Monitor 2019]. Stichting Media Perspectives.

Ministry of Infrastructure and Water Management. (2010). Nota Ruimte 'Rotterdam Stadshavens' [Planning note 'Rotterdam CityPorts']. https://www. rijksoverheid.nl/binaries/rijksoverheid/documenten/ brochures/2010/06/01/nederland-verandertrotterdam-stadshavens/nederland-verandertroterdam-stadshavens.pdf

Municipality of Rotterdam and Port of Rotterdam Authority. (2011). Stadshavens Rotterdam Structuurvisie [CityPorts Rotterdam spatial planning vision].

OECD. (2013). The competitiveness of global portcities: Synthesis report. http://dx.doi.org/10.1787/ 9789264205277-en

Ontwikkelingsmaatschappij Stadshavens NV. (2005). Stadshavens Rotterdam: Ontwikkeling strategie [CityPorts Rotterdam: Development strategy].

Parola, F., \& Maugeri, S. (2013). Origin and taxonomy of conflicts in seaports: Towards a research agenda. Research in Transport Business \& Management, 8, 114-122.

Port of Rotterdam. (2018). RDM Rotterdam en M4H Rotterdam vormen samen het Makers District [RDM Rotterdam and M4H Rotterdam form the Makers District]. https://www.portofrotterdam.com/nl/nieuws- en-persberichten/rdm-rotterdam-en-m4hrotterdam-vormen-samen-het-makers-district

Programmabureau Rotterdam Makers District. (2019). Toekomst in de Maak. Ruimtelijk Raamwerk voor $\mathrm{M} 4 \mathrm{H}$ [Future in the making. Spatial framework for $\mathrm{M} 4 \mathrm{H}]$.

Publieke Dienstverlening op de Kaart. (2021). Basisregistratie Topografie Achtergrondkaarten [Basis registration topography background map layers]. https:// www.pdok.nl/introductie/-/article/basisregistratietopografie-achtergrondkaarten-brt-a-

Rotterdam Makers District. (2021a). M4H Rotterdam. https://m4hrotterdam.nl

Rotterdam Makers District. (2021b). RDM Rotterdam. https://www.rdmrotterdam.nl

Smit, A. J. (2011). The influence of district visual quality on location decisions of creative entrepreneurs. Journal of the American Planning Association, 77(2), 167-184.

Smith, H., \& Garcia Ferrari, M. S. (2012). Waterfront regeneration: Experiences in city-building. Routledge.

Stadshavens Rotterdam. (2009). Gebiedsplan Merwehaven-Vierhavens [Area plan MerwehavenVierhavens].

Stouten, P. (2017). Gentrification and urban design in the urban fabric of Rotterdam. Journal of Urban Regeneration and Renewal, 11(1), 92-103.

TIR Consulting Group. (2016). The third industrial revolution roadmap next economy for the metropolitan region of Rotterdam and The Hague.

Tomlinson, P. R., \& Branston, R. (2014). Turning the tide: Prospects for an industrial renaissance in the North Staffordshire ceramics industrial district. Cambridge Journal of Regions, Economy and Society, 7(3), 489-507.

Van den Berg, B., Vunderink, L., van Wieren, C., Nijland, A., Willems, B., \& Perdeck, N. (2019). Keileboek [Keilebook]. Drukwerkdeal.

Van den Berghe, K., \& Vos, M. (2019). Circular area design or circular area functioning? A discourse-institutional analysis of circular area developments in Amsterdam and Utrecht, The Netherlands. Sustainability, 11(18), 4875.

Wiegmans, B., \& Louw, E. (2011). Changing port-city relations at Amsterdam: A new phase at the interface? Journal of Transport Geography, 19(4), 575-583.

Witte, P., Slack, B., Keesman, M., Jugie, J.-H., \& Wiegmans, B. (2018). Facilitating start-ups in port-city innovation ecosystems: A case study of Montreal and Rotterdam. Journal of Transport Geography, 71, 224-235.

Wolf-Powers, L., Doussard, M., Schrock, G., Heying, C., Eisenburger, M., \& Marotta, S. (2017). The maker movement and urban economic development. Journal of the American Planning Association, 83(4), 365-376.

Wolfrum, S. (2018). Porous city: From metaphor to urban agenda. Birkhäuser. 


\section{About the Authors}

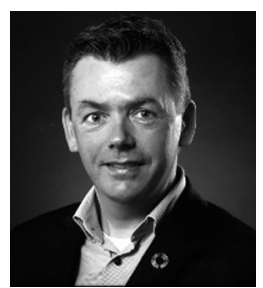

Maurice Jansen is Senior Researcher at Erasmus Centre for Urban, Port and Transport Economics. Maurice considers ports and port cities as breeding grounds for talent, innovation, and entrepreneurship. His research focuses on sustainable port city ecosystems. With his PhD research he seeks to answer to the question of how ports and port cities can develop sustainably, thereby striking a balance between economic, social, and cultural values.

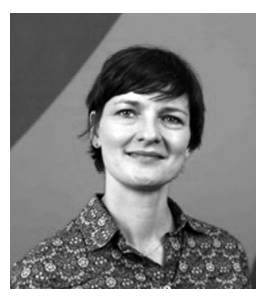

Amanda Brandellero is Associate Professor at the Erasmus School of History, Culture and Communication. Her research focuses on the intersection of culture, creative industries, and place. With a background in economic geography, she is currently leading a project entitled Crafting Future Urban Economies, on sustainable making and craft practices in post-industrial cities. The project is financed by the Dutch Research Council.

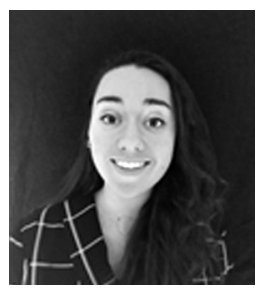

Rosanne van Houwelingen is Junior Researcher at the Erasmus Centre for Urban, Port and Transport Economics (Erasmus UPT). She has graduated at the Erasmus University with a master's degree in Urban, Port and Transport Economics. During her Master thesis, she investigated how redevelopment of old port areas can contribute to strengthening of the port-city relationship. She now works full-time at Erasmus UPT and wants to delve more deeply into research into the port economy and designing education programmes. 